\title{
Kinerja Keuangan Sebagai Variabel Moderasi Antara Faktor Modal Intelektual Dengan Nilai Perusahaan Manufaktur
}

\author{
Liliek Nur Sulistiyowati \\ Universitas PGRI Madiun \\ Jalan Auri 12-14 Madiun, Indonesia \\ e-mail: ${ }^{1}$ liliek1702@gmail.com
}

\begin{abstract}
Informasi Artikel
Diterima: 16-02-2021

Direvisi: 23-03-2021

Disetujui: 18-04-2021

Abstrak

Salah satu komponen yang sangat penting dalam mempertahankan competitive advantage adalah modal intelektual (intellectual capital). Modal intelektual adalah aset yang sifatnya tidak berwujud yang dimiliki perusahaan untuk menggerakkan kinerja perusahaan dan mempunyai karakteristik yang berbeda dari perusahan lain. Modal intelektual pada penelitian ini terdiri atas aset sumber daya manusia (VAHU), aset struktural (STVA) dan aset capital employed (VACA). Penelitian ini bertujuan untuk membuktikan pengaruh modal intelektual yang terdiri atas VAHU, STVA dan VACA terhadap kinerja keuangan perusahaan. Selain itu untuk membuktikan pengaruh modal intelektual terdiri atas VAHU, STVA dan VACA terhadap nilai perusahaan dan membuktikan kinerja keuangan sebagai variabel moderasi diantara modal intelelektual terdiri atas VAHU, STVA dan VACA dengan nilai perusahaan. Sampel penelitian terdiri atas 30 perusahaan manufaktur yang terdaftar di Bursa Efek Indonesia (BEI) pada tahun 2017 sampai dengan 2019. Teknik analisis data yang dipergunakan adalah model analisis jalur. Hasil penelitian yang diperoleh adalah variabel VAHU dan STVA berpengaruh signifikan dan positif terhadap kinerja perusahaan sementara itu pada VACA tidak berpengaruh signifikan. Modal intelektual yaitu VAHU, STVA dan VACA berpengaruh signifikan dan positif terhadap nilai perusahaan. Kinerja keuangan mampu memoderasi modal intelektual pada STVA dengan nilai perusahaan.
\end{abstract}

Kata Kunci: modal intelektual, VAHU, STVA,VACA, kinerja keuangan, nilai perusahaan

\begin{abstract}
One of the most important components in maintaining a competitive advantage is intellectual capital. Intellectual capital is an intangible asset that is owned by the company to drive the company's performance and has different characteristics from other companies. Intellectual capital in this study consists of human resource assets (VAHU), structural assets (STVA), and capital employed assets (VACA). This study aims to prove the effect of intellectual capital consisting of VAHU, STVA, and VACA on the company's financial performance. Besides proving the effect of intellectual capital consisting of VAHU, STVA, and VACA on firm value and proving financial performance as a moderating variable between intellectual capital consisting of VAHU, STVA, and VACA with firm value. The research sample consisted of 30 manufacturing companies listed on the Indonesia Stock Exchange (IDX) from 2017 to 2019. The data analysis technique used was the path analysis model. The results obtained are that the VAHU and STVA variables have a significant and positive effect on company performance, while VACA has no significant effect. Intellectual capital, namely VAHU, STVA, and $V A C A$, has a significant and positive effect on firm value. Financial performance can moderate intellectual capital in STVA with firm value.
\end{abstract}

Keywordss: intellectual capital, VAHU, STVA, VACA, financial performance, firm value

\section{Pendahuluan}

Sumber daya fisik maupun non fisik yang jumlahnya terbatas memicu perusahaan untuk melakukan investasi sehingga dapat meningkatkan kinerja perusahaan (Chen, Cheng, \& Hwang, 2005). Sesuai IAI 2011, aset dalam bentuk modal intelektual merupakan komponen penting dalam mempertahankan competitive advantage. Istilah modal intelektual muncul karena pada PSAK No. 19 (revisi 2011) tentang aset tidak berwujud didefinisikan sebagai aset non moneter untuk memenuhi opersional perusahaan (Wijayani, 2017). Sesuai pendapat (Ikhsan, 2008) modal intelektual adalah jumlah keseluruhan aktiva tidak berwujud dari kepemilikan perusahaan. Sesuai (Pangestika \& Murdianingrum, 2014) modal intelektual meliputi semua daya dan wawasan perusahaan dapat 
meningkatkan kinerjanya. Gunawan dkk (2013) menjelaskan modal intelektual adalah aktiva tak berwujud terdiri dari infornasi dan pengetahuan yang digunakan untuk meningkatkan produktivitas perusahaan, sesuai pendapat Puspitasari (2011) modal intelektual adalah kemampuan berpikir serta wawasan yang mendorong nilai tambah yang lebih spesifik yang dimiliki oleh perusahaan. (Riadi, 2017). Menurut (Geus, 1997) masa sekarang adalah masa dimana semua informasi yang berkaitan dengan lingkungan usaha penuh dengan ketidakpastian, pembaharuan, bersifat beragam dan sementara serta tidak teratur sehingga menimbulkan turbulent. Jadi dari kondisi yang seperti ini perusahaan tidak hanya dituntut untuk memperbanyak hard capital, tetapi juga soft capital, sehingga perusahaan mempunyai daya saing dan keunggulan yang lebih baik dan berbeda dari perusahaan lain.(Alipour, 2011). Salah satu unsur modal intelektual adalah sumber daya manusia (human capital), dimana pada perusahaan masih terdapat kendala, salah satunya skill terhadap insentif finance. Untuk memperoleh tenaga kerja yang unggul, bank dunia merilis human capital index sehingga kualitas sumber daya manusia dapat diukur secara global (Vebri, 2018). Pada era globalisasi yang permasalahannya semakin kompleks berdampak pada perubahan pola investasi industri, dari investasi yang bersifat tangible bergeser ke investasi intangible. Pulic (2000) menilai proses penciptaan nilai sangat penting sebagai pengganti investasi.(Wany, 2010). Perusahaan manufaktur sebagian besar berinvestasi ke modal intelektual yang bersifat intangible yang mempunyai pengaruh langsung terhadap kinerja keuangan, yang merupakan cermin dari kinerja manajemen perusahaan. Jadi apabila modal intelektual tersebut mampu dikelola oleh perusahaan dengan maksimal maka akan menghasilkan kinerja perusahaan yang maksimal dan kinerja perusahaan tersebut akan tercover dalam kinerja keuangan, dan apabila kinerja perusahaan baik maka akan berdampak pada nilai perusahaan yang meningkat pula.

Beberapa penelitian yang relevan antara lain dilakukan oleh (Putri \& Nuzula, 2019) memperoleh kesimpulan berbeda, dimana modal intelektual (intellectual capital) berpengaruh positif pada nilai perusahaan dan modal intelektual (intellectual capital) tidak berpengaruh terhadap kinerja keuangan. Berbeda kesimpulan dengan (Wergiyanto \& Wahyuni, 2016) yang menjelaskan modal intelektual (intellectual capital) mempunyai pengaruh negatif terhadap nilai perusahaan.

Berdasarkan latar belakang masalah diatas maka rumusan masalah dari penelitian ini adalah apakah modal intelektual yang terdiri atas VAHU, STVA dan VACA berpengaruh terhadap kinerja keuangan perusahaan pada perusahaan manufaktur? Pertanyaan penelitian lainnya, apakah modal intelektual yang terdiri atas VAHU, STVA dan VACA berpengaruh terhadap nilai perusahaan pada perusahaan manufaktur? Apakah kinerja keuangan mampu memoderasi modal intelektual yang terdiri atas VAHU, STVA dan VACA dengan nilai perusahaan pada perusahaan manufaktur?

Penelitian ini bertujuan untuk membuktikan modal intelektual yang terdiri atas VAHU, STVA dan VACA berpengaruh terhadap kinerja keuangan pada perusahaan manufaktur. Selanjutnya untuk membuktikan modal intelektual yang terdiri atas VAHU, STVA dan VACA berpengaruh terhadap nilai perusahaan pada perusahaan manufaktur serta untuk membuktikan kinerja keuangan mampu memoderasi modal intelektual yang terdiri atas VAHU, STVA dan VACA dengan nilai perusahaan pada perusahaan manufaktur. Penelitian ini difokuskan pada perusahaan manufaktur yang terdaftar di BEI 2017 - 2019.

\section{Modal Intelektual (Intellectual Capital)}

Modal intelektual (Intellectual Capital) (Bontis et.al) ada beberapa 3 konsep yaitu HC adalah semua aktivitas yang dihasilkan oleh karyawan, SC merupakan aset yang bersifat non human dan $\mathrm{CC}$ adalah pengetahuan yang melekat yang digunakan untuk menjalankan perusahaan.(Ulum, 2007). Value Added Intellectual Coefficient (VAICTM) dari Pulic sejauh ini masih menjadi tolok ukur yang efisien dalam pengukuran human capital.(Chen, 2005)

\section{VAHU - Value Added Human Capital (Human Capital)}

Yang dimaksud dengan modal sumber daya manusia (Human Capital) merupakan semua gaji dan upah dalam satu tahun serta kontribusi dari karyawan yang merupakan segala sumber inspirasi dan kreatifitas yang dicerminkan dalam bentuk ketrampilan dan kompetensi yang dihasilkan ke perusahaan (Dženopoljac, 2014).

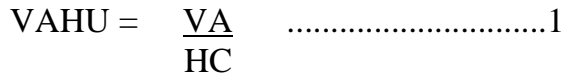

Keterangan:

VA (Value Added) adalah selisih daripada nilai output dikurangi dengan nilai input (dalam rupiah). Modal manusia/HC (Human Capital) adalah total yang dikeluarkan untuk karyawan.(Septia, 2018)

\section{STVA - Stuctural Capital value Added (Structural Capital)}

Sructural Capital dipresentasikan semua perangkat lunak dan keras, struktur organisasi, merk dan paten yang dimiliki oleh perusahaan.(Dženopoljac, 2014) Rumus :

$$
\mathrm{STVA}=\frac{\mathrm{SC}}{\mathrm{VA}}
$$

Dimana:

SC (StructuralCapital) diperoleh dari pengurangan nilai VA dengan modal sumber daya manusia (HC) VA (Value Added) adalah selisih dari nilai output dikurangi dengan input (dalam rupiah) 
Modal manusia/HC (Human Capital) adalah besarnya beban gaji dan upah atau seluruh pengeluaran untuk karyawan (Septia, 2018)

\section{VACA - Value Added Capital Employed} (Pysical Capital)

Semua investasi dan fakor produksi yang bersifat intangible dan tangible yang dimiliki perusahaan untuk menciptakan efisiensi keuangan perusahaan. Untuk mengukur value added digunakan indikator VACA dengan physical capital atau Capital Employed. (Dženopoljac, 2014)

Persamaan :

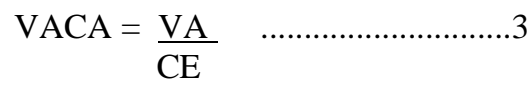

\section{Keterangan:}

VA $($ Value Added $)=$ Output - Input (dalam rupiah) $\mathrm{CA} / \mathrm{CE}($ Capital Employed $)=$ Dana yang tersedia (ekuitas, laba bersih). (Thaib, 2013)

\section{Kinerja Keuangan}

Kinerja keuangan merupakan pencapaian tujuan, visi dan misi perusahaan. Kinerja keuangan tercermin dalam laporan keuangan perusahaan.(Tjandrakirana \& Monika, 2014). Sesuai Roos et al.,(2005), metode pengukuran Intellectual Capital secara umum ada 4 kelompok yaitu (i) metode IC langsung, (ii) metode kapitalisasi pasar, (iii) metode ROA, (iv) metode scorecard.(Dženopoljac, 2014). Return On assets (ROA) merupakan metode untuk mengukur jumlah profit yang diperoleh dalam setiap rupiah yang dimiliki perusahaan.(Nikmah \& Apriyanti, 2016). Untuk pencatatan ROA ada 2 metode meliputi penghitungan total assets pada tanggal tertentu dan menghitung rata - rata total aset (average total assets).(Rahmah, 2019).

$$
\text { Return On Assets }=\frac{\text { Laba Bersih }}{\text { Total Assets }} \text {....4 }
$$

Nilai Perusahaan

Merupakan nilai pasar yang tercermin pada harga saham perusahaan tersebut (Tjandrakirana \& Monika, 2014) Semakin tinggi harga saham berarti nilai perusahaan semakin baik juga. Metode yang digunakan untuk menghitung nilai perusahaan adalah (Wardana, 2019) :

Tobin's $Q$

$$
\mathrm{Q}=\frac{(E M V+D)}{(E B V+D)}
$$

Dimana :

- $\mathrm{Q}=$ nilai perusahaan

- $\quad \mathrm{EMV}=$ nilai pasar ekuitas

- $\quad \mathrm{EBV}$ = nilai buku dari total aktiva

- $\mathrm{D}=$ nilai buku dari total utang

\section{Hubungan Modal Intelektual terhadap Kinerja Keuangan}

Keberhasilan perusahaan dapat dilihat dari kinerja perusahaan dan hal tersebut tercermin dalam kinerja keuangan, yang bersifat tangible dan intangible (Baroroh, 2013). Laporan keuangan berhubungan dengan lingkungan perusahaan yang didalamnya terdapat unsur - unsur modal intelektual, dimana laporan keuangan tersebut diukur dengan rasio - rasio yang mencerminkan kondisi perusahaan (Dzenopoljac, Bontis, \& Janosevic, 2016).

\section{Hubungan Modal Intelektual dan Nilai Perusahaan}

Modal intelektual yang bersifat intangible yang berbentuk keahlian sumber daya manusia, konsep dan strategi perusahaan secara tidak langsung berpengaruh terhadap nilai perusahaan. Dari penerapan strategi - strategi inilah perusahaan dapat mengatur asset - asset non material sehingga efektifitas dan efisiensi dapat tercapai (Dzenopoljac et al., 2016). Modal intelektual mempunyai pengaruh langsung terhadap produktivitas perusahaan dan komponen Modal intelektual memoderasi hubungan antara capital employed dan profitabilitas (Bayraktaroglu Ayse, 2019).

\section{Hubungan Kinerja Keuangan dengan Nilai Perusahaan}

Antara kinerja keuangan dan nilai perusahaan terdapat hubungan yang kuat, apabila nilai perusahaan baik, itu cerminan dari kinerja keuangan yang baik pula(Dj, Artini, \& Suarjaya, 2012). Menurut (Tjandrakirana \& Monika, 2014) efisiensi dan efektifitas kinerja keuangan biasanya diukur dengan ROA atau ROE, kinerja keuangan suatu perusahaan baik, maka nilai perusahaan juga baik, hal tersebut tercermin dari harga saham perusahaan tersebut.

Dari uraian yang sudah dijelaskan diatas maka dapat digambarkan kerangka pikir sebagai berikut:

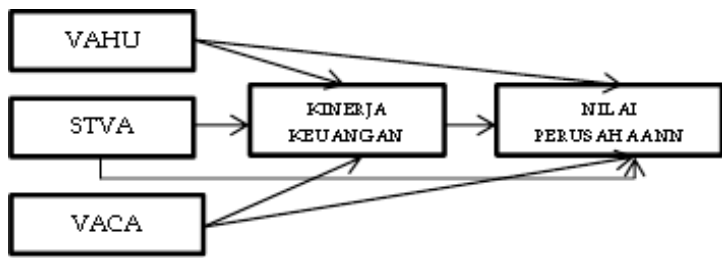

Gambar 1. Kerangka Pikir Penelitian

Beberapa penelitian yang menunjukkan adanya pengaruh signifikan dan positif diantara variabel modal intelektual dan kinerja keuangan perusahaan. Kinerja keuangan diukur dengan ROA yang merupakan rasio profitabilitas perusahaan Tan, Plowman \& Hancock, 2007; Makki, Lodhi \& Rohra, 2009; Firer and Stainbank, 2003 (Ozkan, Cakan, \& Kayacan, 2017). Value Added Intelectual Capital (VAIC) berpengaruh positif dan signifikan 
terhadap kinerja keuangan perusahaan .(Rachmawati, Hayati, \& Yulandi, 2018). Berdasarkan temuan tersebut dapat dirumuskan hipotesis pertama penelitian sebagai berikut:

H1 : Modal intelektual terdiri atas VAHU, STVA dan VACA berpengaruh terhadap kinerja keuangan perusahaan

Modal intelektual dan nilai pasar perusahaan memiliki hubungan yang positif dan signifikan sesuai Wang (2008) dan Tseng \& Goo, (2005). Penelitian lain juga menemukan adanya hubungan positif antara modal intelektual dan nilai pasar perusahaan sesuai Samiloglu (2006); Mehralian, Rajabzadeh \& Rasekh (2012); Ferraro \& Veltri (2011), dalam (Ozkan et al., 2017). Berdasarkan temuan penelitian-penelitian tersebut maka dapat dirumuskan hipotesis kedua penelitian sebagai berikut:

H2 : Modal intelektual terdiri atas VAHU, STVA dan VACA berpengaruh terhadap nilai perusahaan

Pemanfaatan faktor produksi akan meminimalisasi biaya untuk menghasilkan keuntungan yang lebih besar yang pada akhirnya juga akan berpengaruh terhadap peningkatan nilai perusahaan. Hal tersebut akan memperkuat pengaruh dari modal intelektual terhadap nilai perusahaan (Simarmata dan Subowo, 2014) dalam (D. A. D. Lestari \& Satyawan, 2018). Untuk temuan tersebut maka dapat dirumuskan hipotesis ketiga penelitian sebagai berikut:

H3 : Kinerja keuangan perusahaan merupakan variabel pemoderasi antara modal intelektual terdiri atas VAHU, STVA dan VACA dengan nilai perusahaan.

\section{Metode Penelitian}

Seluruh perusahaan manufaktur yang ada di Bursa Efek Indonesia (BEI) mulai tahun 2017 sampai dengan tahun 2019 adalah populasi penelitian. Tahun 2017 sampai dengan 2019 terdapat 182 perusahaan manufaktur yang ada di BEI yang terdiri atas sektor industri dasar dan kimia, sektor aneka industri dan sektor industri barang konsumsi. Penelitian mengambil 30 (tiga puluh) perusahaan manufaktur sebagai sampel penelitian. Pengambilan sampel sebanyak 30 (tiga puluh) perusahaan manufaktur didasarkan pada pertimbangan, minimal unit analisis yang bisa dilakukan analisis mendalam jika terdiri atas minimal 30 (tiga puluh) sampel (Sugiyono, 2012). (A. Lestari, 2016)

Pemilihan perusahaan manufaktur sebagai sampel penelitian juga didasari pada beberapa pertimbangan antara lain, pertama, pada umumnya perusahaan manufaktur merupakan perusahaan berskala besar daripada jenis perusahaan lainnya, kedua pada perusahaan manufaktur biasanya seluruh komponen modal intelektual ada mulai dari aset sumber daya manusia (VAHU), aset struktural (STVA) sampai dengan aset capital employed (VACA) sesuai dengan pembahasan dalam penelitian, yang ketiga perusahaan manufaktur pada umumnya lebih tahan terhadap goncangan ekonomi dibandingkan perusahaan lainnya.

Variabel dalam penelitian ini meliputi 3 (tiga) jenis variabel yaitu:

1. Variabel eksogen $(\mathrm{X})$ yaitu modal intelektual Modal intelektual terdiri dengan 3 (tiga) variabel yaitu: a). VAHU $\left(\mathrm{X}_{1}\right)$ - Value Added Human Capital (Human Capital) adalah faktor intellectual capital yang diperoleh dari modal sumber daya manusia (SDM) perusahaan. b). STVA $\left(\mathrm{X}_{2}\right)$ - Stuctural Capital value Added (Structural Capital) adalah faktor intellectual capital yang diperoleh dari nilai tambah struktur permodalan yang dimiliki perusahaan. c). VACA $\left(\mathrm{X}_{3}\right)$ - Value Added Capital Employed (Pysical Capital) yaitu faktor intellectual capital yang diperoleh dari modal karyawan yang dipekerjakan secara fisik oleh perusahaan.

2. Variabel moderator (moderating variable/Y) yaitu kinerja keuangan perusahaan. Adalah kemampuan perusahaan dalam mengelola seluruh modal keuangan yang dimiliki untuk mencapai tujuan perusahaan. Kinerja keuangan diukur dengan menggunakan indikator Return On Assets (ROA).

3. Variabel endogen (Z) yaitu nilai perusahaan. adalah kinerja perusahaan dari sudut pandang investor. Nilai perusahaan dapat dilihat dari kemampuan perusahaan memberikan keuntungan bagi investor. Nilai perusahaan diukur dari peningkatan harga saham perusahaan (Q).

Analisis jalur (path analysis) merupakan model analisis yang dipilih untuk menjawab tujuan penelitian. Analisis jalur merupakan pengembangan model regresi linear berganda dan model regresi bivariate.(Ghozali, 2008). Analisis jalur juga dimungkinkan melakukan pengujian dengan menggunakan variabel moderating atau variabel intervening. Dalam analisis jalur juga diukur pengaruh langsung dan pengaruh tidak langsung diantara variabel-variabel dalam model (Ghozali, 2008)

Untuk melihat pengaruh variabel moderasi dipergunakan uji Sobel (Ghozali, 2008) yang bertujuan melihat apakah variabel moderasi berpengaruh signifikan dalam memoderasi variabel eksogen dengan variabel endogen.

\section{Hasil dan Pembahasan}

Deskripsi Variabel VAHU (Value Added Human Capital (Human Capital)

Hasil deskripsi variabel VAHU sebagaimana di Tabel 1. 
Tabel 1. Deskripsi Variabel VAHU

\begin{tabular}{rlrrr}
\hline No & Tahun & $\begin{array}{r}\text { Rata-Rata } \\
\text { (Mean) }\end{array}$ & Minimal & Maksimal \\
\hline 1 & 2017 & 57,65 & 8.32 & 579.28 \\
2 & 2018 & 60,08 & 0,52 & 429.89 \\
3 & 2019 & 54,42 & 8.17 & 348,54 \\
& Rata-Rata & 57,66 & 0,52 & 579,28 \\
& Total & & & \\
\hline
\end{tabular}

Sumber : Data Penelitian, diolah

Sesuai Tabel 1 menunjukkan rata-rata VAHU dari perusahaan manufaktur yang tercatat di BEI pada tahun 2017 sebesar 57,65. Nilai minimum 8,32 diperoleh saham LION, nilai maksimum 579,28 diperoleh saham BAJA. Nilai minimum VAHU tahun 2018 0,52 diperoleh perusahaan saham KIAS. Nilai tertinggi 429.89 diperoleh saham TBMS. Rata-rata VAHU sebesar 60.08. Nilai minimum 2019 8,17 diperoleh saham LION. Nilai tertinggi 348.54 diperoleh saham TBMS. Rata-rata VAHU sebesar 54.42. Dari hasil analisis deskriptif VAHU menunjukkan pada tahun 2017-2019 memiliki nilai VAHU positif. Ini mengindikasikan output yang diperoleh perusahaan lebih tinggi dibandingkan dengan input yang dikeluarkan perusahaan.

\section{Deskripsi Variabel STVA (Structural Capital Value Added).}

Hasil deskripsi variabel STVA dapat dilihat pada Tabel 2

Tabel 2. Deskripsi Variabel STVA

\begin{tabular}{lcccc}
\hline No & Tahun & $\begin{array}{c}\text { Rata- } \\
\text { Rata } \\
\text { (Mean) }\end{array}$ & Minimal & Maksimal \\
\hline 1 & 2017 & 1,0347 & 1,0017 & 1,1203 \\
2 & 2018 & 1,0343 & 0,9977 & 1,1315 \\
3 & 2019 & 1,0381 & 1,0006 & 1,1248 \\
\multicolumn{2}{l}{ Rata-Rata Total } & 1,0355 & 0,9977 & 1,1315 \\
\hline
\end{tabular}

Sumber : Data Penelitian, diolah

Berdasarkan Tabel 2 menunjukkan ratarata STVA pada tahun 2017 sebesar 1,0347. Nilai minimum 1,0017 diperoleh saham BAJA. Nilai maksimum 1,1203 diperoleh saham LION. Nilai minimum STVA 2018 0,9977 diperoleh saham TBMS, nilai tertinggi 1,1315 diperoleh saham KIAS. 2018 menunjukkan rata-rata STVA sebesar 1.0343. Nilai minimum STVA 2019 sebesar 1,0006 diperoleh saham ALKA. Nilai tertinggi 1,1248 diperoleh saham AUTO, rata-rata STVA sebesar 1.0381. Hasil analisis deskriptif variabel STVA menunjukkan nilai positif Hal ini menunjukkan perusahaan mampu mengelola dengan baik structural capital yang dimiliki dalam menghasilkan VA perusahaan.

\section{Deskripsi Variabel VACA (Value Added Capital Employed)}

Hasil deskripsi variabel VACA dapat dilihat pada Tabel 3

Tabel 3. Deskripsi Variabel VACA

\begin{tabular}{ccccc}
\hline No & Tahun & $\begin{array}{c}\text { Rata-Rata } \\
\text { (Mean) }\end{array}$ & Minimal & Maksimal \\
\hline 1 & 2017 & 3,1657 & 0,1912 & 40,8471 \\
2 & 2018 & 4,9652 & 0,0312 & 129,7325 \\
3 & 2019 & 2,9191 & 0,2292 & 30,1003 \\
Rata-Rata & 3,7518 & 0,0312 & 129,7325 \\
\multicolumn{3}{c}{ Total } \\
\multicolumn{3}{l}{ Sumber: Data Penelitian, diolah } \\
\end{tabular}

Tabel 3 menunjukkan nilai minimum VACA tahun 2017 sebesar 0,1912 diperoleh saham SMBR, nilai maksimum 40,8471 diperoleh perusahaan saham ALKA. Rata-rata sebesar 3,1657. Nilai minimum VACA tahun 2018 0,0312 diperoleh saham KIAS. Nilai tertinggi 129,7325 diperoleh saham BAJA. Tahun 2018 menunjukkan rata-rata 4.9652 . Nilai minimum VACA tahun 2019 0,2292 diperoleh saham SMBR. Nilai tertinggi periode 2019 sebesar 30,1003 diperoleh saham MYOR Rata-rata VACA sebesar 2.919. Tahun $2017 \quad-2019$ menunjukkan nilai VACA positif. Hal ini menunjukkan perusahaan mampu mengelola dengan baik capital employed yang dimiliki dalam memperoleh VA perusahaan.

\section{Deskripsi Variabel Kinerja Keuangan Perusahaan}

Hasil deskripsi variabel kinerja keuangan perusahaan (ROA) dapat dilihat pada Tabel 4

Tabel 4. Deskripsi Variabel Kinerja Keuangan Perusahaan (ROA)

\begin{tabular}{ccccc}
\hline No & Tahun & $\begin{array}{c}\text { Rata-Rata } \\
\text { (Mean) }\end{array}$ & Minimal & Maksimal \\
\hline 1 & 2017 & 0,0485 & $-0,0483$ & 0,5267 \\
2 & 2018 & 0,0433 & $-0,1761$ & 0.9210 \\
3 & 2019 & 0.0292 & -0.2544 & 0.2623 \\
\multicolumn{2}{l}{ Rata-Rata Total } & 0,0447 & $-0,2544$ & 1,2040 \\
\hline
\end{tabular}

Sumber : Data Penelitian, diolah

Tabel 4 menunjukkan rata-rata kinerja perusahaan (ROA) tahun 2017 sebesar 0,0485. Nilai minimum -0,0483 diperoleh saham KIAS. PT KIAS memiliki ROA terendah mengindikasikan memperoleh kerugian terbesar. Nilai tertinggi 0,5267 diperoleh saham MLBI. Nilai positif tertinggi PT MLBI menunjukkan perusahaan memperoleh laba terbesar pada 2017. Nilai terendah 2018 -0,1761 diperoleh saham MBTO. Nilai tertinggi 0,9210 diperoleh saham MERK yang menunjukkan PT MERK memperoleh laba terbesar. Nilai terendah 2019 0,2544 diperoleh saham KIAS. Nilai tertinggi 0,2623 diperoleh saham MLBI hal ini menunjukkan PT MLBI memperoleh laba terbesar. 
Deskripsi Variabel Nilai Perusahaan

Hasil deskripsi variabel nilai perusahaan di Tabel 5 sebagai berikut:

Tabel 5 Deskripsi Variabel Nilai Perusahaan

\begin{tabular}{|l|l|l|l|l|}
\hline No & Tahun & $\begin{array}{l}\text { Rata- } \\
\text { Rata } \\
\text { (Mean) }\end{array}$ & Minimal & Maksimal \\
\hline 1 & 2017 & 0,7268 & 0,4246 & 0,9029 \\
\hline 2 & 2018 & 0,7359 & 0,5222 & 2.0723 \\
\hline 3 & 2019 & 0.7097 & 0.1822 & 0.8920 \\
\hline & $\begin{array}{l}\text { Rata- } \\
\text { Rata } \\
\text { Total }\end{array}$ & 0,7254 & 0,1822 & 2,0723 \\
\hline
\end{tabular}

Sumber : Data Penelitian, diolah

Berdasarkan Tabel 5 menunjukkan ratarata nilai 20170,7268 yang berarti rata-rata nilai perusahaan sebesar 0.7268 dari nilai buku (book value) perusahaan. Nilai terendah 0,4246 diperoleh saham MLBI.dan nilai pasar tertinggi 0,9029 dari saham INTP . Nilai terendah 2018 0,5222 saham BAJA. Nilai tertinggi 2,0723 dari saham HMSP. Tahun 2018 menunjukkan rata-rata nilai 0.7359 yang berarti rata-rata perusahaan selama periode 2018 memiliki nilai perusahaan 0,7359 dari nilai bukunya (book value). Nilai terendah 2019 sebesar 0,1822 diperoleh saham WIIM. Nilai tertinggi 0,8920 diperoleh saham EKAD. Rata-rata nilai perusahaan sebesar 0.7097. Rata-rata nilai perusahaan dari 2017 sampai 2019 kurang dari 1 menunjukkan rata-rata kondisi saham perusahaan pada posisi undervalued, hasil ini juga berarti rata-rata perusahaan belum mampu memaksimalkan nilai pasar yang ada.

\section{ANALISIS JALUR (PATH ANALYSIS)}

Berdasarkan hasil pengolahan data didapatkan model diagram jalur (path diagram) seperti pada Gambar 2 sebagai berikut:

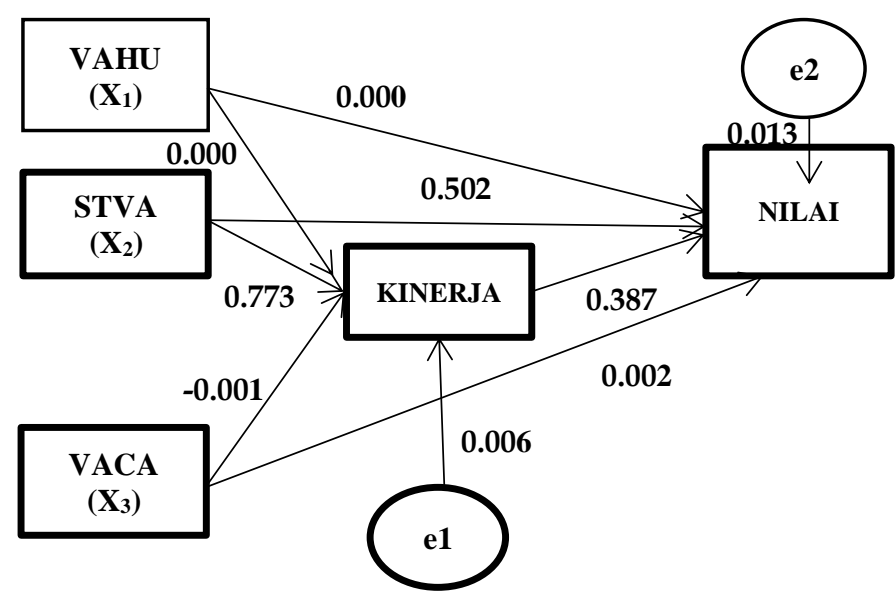

Gambar 2 Diagram Hasil Analisis Jalur

Berdasarkan Gambar 2 diperoleh pengaruh langsung dari masing-masing variabel eksogen
(VAHU, STVA dan VACA) terhadap variabel moderating yaitu kinerja keuangan perusahaan adalah sebagai berikut:

Tabel 6 Pengaruh Langsung Variabel Eksogen terhadap Variabel Moderating

\begin{tabular}{|l|r|r|c|c|}
\hline $\begin{array}{c}\text { Variabel } \\
\text { Eksogen }\end{array}$ & $\begin{array}{c}\text { Pengaruh } \\
\text { Langsung }\end{array}$ & $\begin{array}{c}\text { Critical } \\
\text { Ratio }\end{array}$ & $\begin{array}{c}\text { Sig } \\
\text { Level }\end{array}$ & Kesimpulan \\
\hline VAHU & 0.000 & 2.043 & 0.041 & $\begin{array}{c}\text { Berpengaruh } \\
\text { signifikan }\end{array}$ \\
\hline STVA & 0.773 & 4.518 & 0.000 & $\begin{array}{c}\text { Berpengaruh } \\
\text { signifikan }\end{array}$ \\
\hline VACA & -0.001 & 1.442 & 0.149 & $\begin{array}{c}\text { Tidak } \\
\text { berpengaruh }\end{array}$ \\
\hline
\end{tabular}

Sumber : Data Penelitian, diolah

Tabel 6 menunjukkan terdapat 2 (dua) variabel eksogen yang berpengaruh positif dan signifikan terhadap kinerja keuangan perusahaan. Kedua variabel tersebut adalah VAHU dan STVA. Variabel VAHU berpengaruh positif dan signifikan dengan pengaruh langsung sebesar 0.000. Variabel VAHU berpengaruh signifikan karena memiliki nilai taraf signifikansi 0.041 lebih kecil dari nilai $\alpha$ yang ditetapkan sebesar 0.05 atau 5\%. Variabel STVA memiliki pengaruh positif dan signifikan dengan pengaruh langsung sebesar 0.773 dan berpengaruh signifikan karena memiliki nilai taraf signifikansi sebesar 0.000 lebih kecil dari 0.05 atau 5\%. VACA tidak berpengaruh terhadap kinerja keuangan perusahaan. VACA memiliki pengaruh langsung terhadap kinerja keuangan -0.001. VACA tidak berpengaruh signifikan terhadap variabel kinerja keuangan perusahaan karena memiliki nilai taraf signifikansi sebesar 0.149 lebih besar dari nilai $\dot{\alpha}$ yang ditetapkan sebesar 0.05 atau $5 \%$.

Berdasarkan Gambar 2 diperoleh pengaruh langsung variabel eksogen (VAHU, STVA dan VACA) dan variabel moderating yaitu kinerja keuangan perusahaan terhadap variabel endogen (NILAI PERUSAHAAN). Pengaruh langsung variabel eksogen dan variabel moderating terhadap nilai perusahaan seperti pada Tabel 7 .

Tabel 7 Pengaruh Langsung Variabel Eksogen, Variabel Moderating terhadap Variabel Endogen

\begin{tabular}{|c|c|c|c|c|}
\hline $\begin{array}{c}\text { Variabel } \\
\text { Eksogen \& } \\
\text { Intervening }\end{array}$ & $\begin{array}{l}\text { Pengaruh } \\
\text { Langsung }\end{array}$ & $\begin{array}{l}\text { Critical } \\
\text { Ratio }\end{array}$ & $\begin{array}{l}\text { Signif } \\
\text { Level }\end{array}$ & Kesimpulan \\
\hline VAHU & 0.000 & 3.735 & 0.000 & $\begin{array}{c}\text { Berpengaruh } \\
\text { signifikan }\end{array}$ \\
\hline STVA & 0.502 & 3.122 & 0.002 & $\begin{array}{l}\text { Berpengaruh } \\
\text { signifikan }\end{array}$ \\
\hline VACA & 0.002 & 2.223 & 0.026 & $\begin{array}{c}\text { Berpengaruh } \\
\text { signifikan }\end{array}$ \\
\hline KINERJA & 0.387 & 4.828 & 0.000 & $\begin{array}{c}\text { Berpengaruh } \\
\text { signifikan }\end{array}$ \\
\hline
\end{tabular}

Sumber data : Data penelitian, diolah 
Tabel 7 menunjukkan terdapat 3 (tiga) variabel eksogen yang berpengaruh positif dan signifikan terhadap nilai perusahaan. Ketiga variabel itu VAHU, STVA dan VACA. VAHU berpengaruh positif dan signifikan dengan pengaruh langsung 0.000 dan berpengaruh signifikan karena memiliki nilai taraf signifikansi 0.000 lebih kecil dari nilai $\dot{\alpha}$ 0.05 atau $5 \%$. STVA berpengaruh langsung terhadap nilai perusahaan 0.502 dan berpengaruh positif dan signifikan karena taraf signifikansi 0.002 lebih kecil dari nilai $\dot{\alpha} 0.05$ atau 5\%. VACA memiliki pengaruh positif dan signifikan dengan pengaruh langsung 0.002 dan berpengaruh signifikan karena taraf signifikansi 0.026 lebih kecil dari nilai $\dot{\alpha} \quad 0.05$ atau $5 \%$. Variabel kinerja keuangan perusahaan berpengaruh positif dan signifikan dengan nilai 0.387 dan berpengaruh signifikan terhadap nilai perusahaan karena memiliki nilai taraf signifikansi 0.000 lebih kecil dari nilai $\alpha$ 5\%

\section{Menghitung Pengaruh Tidak Langsung (Faktor Mediasi)}

Hasil pengolahan data menunjukkan STVA berpengaruh signifikan dan positif terhadap nilai perusahaan melalui kinerja keuangan perusahaan sebagai variabel moderasi. Besarnya pengaruh tidak langsung (indirect effect) dari STVA terhadap nilai perusahaan melalui variabel kinerja perusahaan 0.299. Besarnya pengaruh tidak langsung dari STVA terhadap nilai perusahaan melalui kinerja keuangan merupakan perkalian dari pengaruh langsung STVA terhadap kinerja keuangan dan kinerja keuangan terhadap nilai perusahaan. Pengaruh langsung dari STVA ke nilai perusahaan 0.773, dan pengaruh langsung kinerja keuangan terhadap nilai perusahaan 0.387 , sehingga besarnya pengaruh tidak langsung dari STVA terhadap nilai melalui kinerja (0.773 x 0.387) sebesar 0.299. Jadi disimpulkan bahwa kinerja keuangan perusahaan mampu memoderasi variabel STVA terhadap nilai perusahaan.

Untuk melihat apakah pengaruh tidak langsung dari variabel kinerja keuangan perusahaan sebagai variabel moderasi dari STVA dan nilai perusahaan dipergunakan uji Sobel. Berdasarkan hasil pengolahan data, besarnya koefisien pengaruh langsung dari STVA terhadap kinerja keuangan $\left(\beta_{\mathrm{X} 2 . \mathrm{Y}}\right)$ sebesar 0.773 , dengan nilai standar error (SE.X2.Y) sebesar 0.171. Sementara itu besarnya koefisien pengaruh langsung dari kinerja keuangan ke nilai perusahaan ( $\left.\beta_{Y . Z}\right)$ sebesar 0.387 dengan nilai standar error ( $\mathrm{SE}_{\mathrm{Y} . \mathrm{Z}}$ ) sebesar 0.08. Selanjutnya dapat dihitung besarnya standar error pengaruh tidak langsung (indirect effect) dengan menggunakan rumus sebagai berikut:

$$
\begin{aligned}
& \mathrm{S}_{\mathrm{E}}=\sqrt{\left(\beta_{Y Z}^{2} * S E_{X 2 . Y}^{2}\right)+\left(\beta_{X 2 Y}^{2} * S E_{Y Z}^{2}\right)+\left(S E_{X 2 Y}^{2} * S E_{Y Z}^{2}\right)} \\
& S_{\mathrm{E}}=\sqrt{\left(0.387^{2} * 0.171^{2}\right)+\left(0.773^{2} * 0.08^{2}\right)+\left(0.171^{2} * 0.08^{2}\right)} \\
& \mathrm{S}_{\mathrm{E}}=\sqrt{(0.150 * 0.029)+(0.598 * 0,, 006)+(0.029 * 0.006)} \\
& \mathrm{S}_{\mathrm{E}}=\sqrt{0.00435+0.00359+0.000174} \\
& \mathrm{~S}_{\mathrm{E}}=\sqrt{0.00814} \\
& \mathrm{~S}_{\mathrm{E}}=0.0901
\end{aligned}
$$

Besarnya pengaruh tidak langsung STVA terhadap nilai perusahaan melalui kinerja keuangan perusahaan sebagai variabel moderasi ( $\left.\beta_{\mathrm{X} 2 . \mathrm{Y} . \mathrm{Z}}\right)$ sebesar 0.299 sehingga diperoleh nilai thitung untuk pengaruh tidak langsung sebesar

$$
\begin{aligned}
t_{\text {hitung }} & =\beta_{X 2 . Y . Z} / \mathrm{SE} \\
& =0.299 / 0.0901 \\
& =3,32
\end{aligned}
$$

Besarnya $t_{\text {hitung }}$ lebih besar dari $t_{\text {tabel }}$ dengan taraf signifikansi 5\% sebesar 1.98 sehingga dapat ditarik kesimpulan kinerja keuangan perusahaan siginifikan mampu memoderasi variabel STVA dengan variabel nilai perusahaan.

Hasil analisis jalur menunjukkan VAHU dan STVA berpengaruh positif dan signifikan terhadap kinerja keuangan perusahaan. STVA memiliki pengaruh lebih besar terhadap kinerja keuangan dari pada VAHU. Ini dibuktikan dari pengaruh langsung STVA lebih besar daripada VAHU terhadap kinerja keuangan perusahaan. Hasil penelitian diatas relevan dari beberapa penelitian terdahulu yang menemukan fakta bahwa variabel human capital (VAHU) dan struktur capital (STVA) adalah faktor penting bagi kinerja perusahaan. Kedua variable tersebut memiliki pengaruh positif dan signifikan terhadap kinerja perusahaan.(Sharabati, Jawad, \& Bontis, 2010). Human capital (VAHU) dan structural capital (STVA) merupakan faktor yang memberikan pengaruh yang positif dan kuat terhadap pada perbankan di Nigeria(Onyekwelu, Okoh, \& Iyidiobi, 2017). Penelitian yang dilakukan (Ozkan et al., 2017) menyimpulkan investasi perusahaan pada bidang sumber daya manusia (HC) menghasilkan nilai tambah bagi perusahaan (VAHU) yang memiliki pengaruh positif dan signifikan pada tingkat keuntungan lebih tinggi dari perbankan di Turki. Penelitian lainnya juga membuktikan terdapat pengaruh signifikan dari modal intelektual yang berasal dari modal sumber daya manusia (VAHU) terhadap kinerja keuangan. (Arifa \& Ahmar, 2016). Kinerja perusahaan paling utama berasal dari aset sumber daya manusia (HC). Aset sumber daya manusia (HC) diperoleh dari pendidikan dan pengalaman kerja. Pengalaman dan pendidikan manajemen puncak perusahaan adalah faktor yang tidak bisa ditiru dan langka sehingga tidak mudah diduplikasi oleh perusahaan lainnya. Nilai tambah yang berasal dari aset sumber daya manusia (VAHU) memiliki dampak terbesar terhadap produktifitas dan profitabilitas perusahaan yang menggambarkan kinerja keuangan perusahaan (Kamath, 2008) dalam (Molodchik Mariia, Jardon Carlos, \& Bykova Anna, 2019). Structural capital (SC) bagian dari usaha menciptakan nilai tambah perusahaan (STVA) memiliki pengaruh positif dan signifikan terhadap profitabilitas. Hal ini mengindikasikan nilai tambah (VA) yang diciptakan modal structural perusahaan (aset fisik) merupakan indikator kinerja keuangan perusahaan yang 
memberikan keyakinan investor untuk melakukan investasi (Firer \& Williams, 2013). Variabel structural capital memiliki pengaruh paling tinggi terhadap kinerja keuangan perusahaan(Gozali \& Hatane, 2014). Variabel modal intelektual yang memberikan kontribusi tertinggi terhadap kinerja keuangan perusahaan berasal dari aset perusahaan yang berasal dari structural capital/STVA.(Mariya, Olga, \& Jana, 2011).

Hasil penelitian ini memberikan kesimpulan adanya pengaruh signifikan dan positif antara variabel modal intelektual yang terdiri atas VAHU, STVA dan VACA dengan nilai perusahaan. Hasil penelitian menunjukkan ketiga variabel eksogen (VAHU, STVA dan VACA) berpengaruh positif dan signifikan terhadap nilai perusahaan. Hasil penelitian diatas relevan dengan penelitian yang dilakukan Najibullah (2005) dalam (Gozali \& Hatane, 2014) yang menemukan fakta modal intelektual berpengaruh positif dan signifikan terhadap nilai perusahaan. Menurut Brahamkar (2007) dalam (Mariya et al., 2011) berkesimpulan adanya pengaruh positif modal intelektual terhadap harga pasar saham dan tingkat pengembalian saham perusahaan yang merupakan indikator nilai perusahaan. Perusahaan yang mampu melakukan efisiensi sehingga menghasilkan nilai tambah (VA) pada aset sumber daya manusia (VAHU), structural capital (STVA) dan aset fisik (VACA) akan berpengaruh positif terhadap nilai pasar perusahaan (market value). Kondisi akan meyakinkan investor untuk melakukan investasi pada perusahaan di masa mendatang (Chen, et al, 2015) dalam (Leon, 2017)

Investasi yang dilakukan dalam hal sumber daya manusia (HC) dan capital employed (CE) memiliki pengaruh positif dan signifikan terhadap nilai pasar perusahaan. Nilai tambah yang diperoleh dari efisiensi investasi di bidang sumber daya manusia (VAHU) dan sumber daya fisik (VACA) berpengaruh positif dan signifikan terhadap nilai pasar perusahaan (Maditinos, Chatzoudes, Tsauridis \& Theriou (2011), Nekouizadeh \& Ghaedi, (2012) dalam (Ozkan et al., 2017). Variabel STVA memiliki kontribusi terbesar terhadap nilai perusahaan. Variabel human capital (VAHU) memiliki kontribusi terbesar kedua terhadap nilai perusahaan.(Gozali \& Hatane, 2014). Temuan penelitian tersebut relevan dengan penelitian Fathi, Farahman dan Khorasani ( 2013) dan Kai, et al (2011) dalam (Gozali \& Hatane, 2014) menyatakan STVA mempunyai pengaruh paling signifikan terhadap nilai perusahaan.

Hasil penelitian lain menyimpulkan ada pengaruh moderasi dari variabel modal intelektual terhadap nilai perusahaan melalui kinerja keuangan perusahaan pada variable STVA. Dari tiga variabel modal intelektual hanya satu variabel modal intelektual yang mampu dimoderasi oleh kinerja keuangan yaitu variabel structural capital (STVA). Besarnya pengaruh tidak langsung yang memediasi
STVA pada nilai perusahaan melalui kinerja keuangan sebesar 0.299. Sementara itu 2 (dua) variabel lainnya VAHU dan VACA tidak dapat dimoderasi oleh kinerja keuangan terhadap nilai perusahaan. Kinerja keuangan perusahaan yang ditunjukkan melalui tingkat profitabilitas yang tinggi membuat minat investor naik untuk melakukan investasi sehingga dapat meningkatkan nilai perusahaan di mata penanam modal. Melalui kinerja keuangan yang baik maka nilai tambah yang berasal dari structural capital (intangible asset) akan dapat dimaksimalkan untuk meningkatkan nilai perusahaan.(D. A. D. Lestari \& Satyawan, 2018). Profitabilitas mampu memoderasi hubungan antara variabel modal intelektual dengan nilai perusahaan. Dalam penelitian ini ROA sebagai indikator kinerja keuangan perusahaan mampu memoderasi variabel modal intelektual dengan nilai $Q$ tobin yang merupakan indikator nilai perusahaan.(Sayyidah \& Saifi, 2017).

\section{Kesimpulan}

Sesuai pengujian data dan pembahasan, maka dapat disimpulkan:

a. Variabel VAHU dan STVA berpengaruh positif dan signifikan terhadap kinerja keuangan perusahaan. Sementara itu capital employed (VACA) tidak berpengaruh signifikan terhadap kinerja keuangan perusahaan

b. Variabel VAHU, STVA dan VACA berpengaruh positif dan signifikan terhadap nilai perusahaan.

c. Variabel kinerja perusahaan mampu memoderasi hubungan antara variabel modal structural (STVA) dan nilai perusahaan.

\section{Referensi}

Alipour, M. (2011). The Effect of Intellectual Capital on Firm Performance: an Investigation of Iran Insurance Companies. Measuring Business Excellence, 16(1), 5366. doi: 10.1108/13683041211204671

Arifa, P. A., \& Ahmar, N. (2016). The Effect of Intellectual Capital on the Financial Performance of Insurance Companies Listed on the Indonesia Stock Exchange (ISE). The Indonesian Accounting Review, 6(1), 45-54. doi: 10.14414/tiar.v6i1.574 atau

10.14414/tiar.v6i1.852

Baroroh, N. (2013). Analisis Pengaruh Modal Intelektual Terhadap Kinerja Keuangan Perusahaan Manufaktur di Indonesia. Jurnal Dinamika Akuntansi Universitas Diponegoro Indonesia, 5(2), 172-182.

Bayraktaroglu Ayse, E. (2019). Intellectual capital and firm performance: an extended VAIC model. Journal of Intellectual Capital, 
20(3), 406-425. doi: 10.1108/JIC-12-20170184

Chen, M. C. (2005). An Empirical Investigation of the Relationship Between Intellectual Capital and Firms' Market Value and Financial Performance. Journal of Intellectual Capital, 6(2), 159-176. doi: 10.1108/14691930510592771

Chen, M. C., Cheng, S. J., \& Hwang, Y. (2005). An empirical investigation of the relationship between intellectual capital and firms' market value and financial performance. Journal of Intellectual Capital, 6(2), 159176. doi: 10.1108/14691930510592771

Dj, A. M., Artini, L. G. S., \& Suarjaya, A. A. G. (2012). Pengaruh Kinerja Keuangan terhadap Nilai Perusahaan pada Perusahaan Manufaktur di Bursa Efek Indonesia. MATRIK Jurnal Manajemen, Strategi Bisnis, dan Kewirausahaan, 6(2), 130-138.

Dženopoljac, V. (2014). Intellectual Capital: Importance, Measurement, and Impact on Corporate Performance. Ekonomika Preduzeca, 005.336.4;005.96;005.94.

Dzenopoljac, V., Bontis, N., \& Janosevic, S. (2016). Intellectual Capital and Financial Performance in The Serbian Ict Industry. Journal of Intellectual Capital, 17(2), 373396. doi: 10.1108/JIC-07-2015-0068

Firer, S. R., \& Williams, M. (2013). Intellectual Capital and Traditional Measures of Corporate Performance. Journal of Intellectual Capital, 4(3), 348-360. doi: 10.1108/14691930310487806

Geus, A. d. (1997). Resensi Buku :The Living Company Harvard Business School Press

Ghozali, I. (2008). Model persamaan struktural: konsep dan aplikasi dengan program Amos 16.0. Semarang: Badan Penerbit Universitas Diponegoro.

Gozali, A., \& Hatane, S. E. (2014). Pengaruh Intellectual Capital Terhadap Kinerja Keuangan Dan Nilai Perusahaan Khususnya Di Industri Keuangan Dan Industri Pertambangan Yang Terdaftar Di Bursa Efek Indonesia Tahun 20018 - 2012. Business Accounting Review, 2(2), 204213.

Ikhsan, A. (2008). Akuntansi Sumberdaya Manusia: Suatu Tinjauan Penilaian Modal Manusia (1 ed.). Yogyakarta: Graha Ilmu.

Leon, F. M. (2017). Pengaruh Intellectual Capital terhadap Kinerja Keuangan Perusahaan Go Publik di Indonesia. Forum Ilmiah Jurnal Bunga Rampai, 14(2), 140-152.

Lestari, A. (2016). Pengaruh Kepemimpinan Partisipatif dan Komitmen Organisasi terhadap Efektifitas Implementasi Rencana Stratejik pada Madrasah Aliyah di
Kabupaten Sukabumi Jawa Barat. Jurnal Administrasi Pendidikan UPI (JAP), 23(1), 114-129.

Lestari, D. A. D., \& Satyawan, M. D. (2018). Pengaruh Intellectual Capital terhadap Nilai Perusahaan dengan Profitabilitas sebagai Variabel Moderasi. Jurnal Akuntansi AKUNESA, 7(1)

Mariya, M., Olga, A., \& Jana, N. (2011). Intellectual Capital Impact on Financial Performance: Industry Effects. SSRN Electronic Journal. doi: 10.2139/ssrn.2001472

Molodchik Mariia, A., Jardon Carlos, M., \& Bykova Anna, A. (2019). The performance effect of intellectual capital in the Russian context: Industry vs company level. Journal of Intellectual Capital, 20(3), 335354. doi: 10.1108/JIC-10-2018-0190

Nikmah, \& Apriyanti, H. (2016). Pengaruh Intellectual Capital Terhadap Kinerja Keuangan Perusahaan Manufaktur di Bursa Efek Indonesia. Jurnal Akuntansi, 6(1), 53-74. doi: https://doi.org/10.33369/j.akuntansi.6.1.53 $-74$

Onyekwelu, U. L., Okoh, J. I., \& Iyidiobi. (2017). Effect of Intellectual Capital on Financial Performance of Banks in Nigeria. European Journal of Accounting, Auditing and Finance Research, 5(2), 28-57. doi: https://doi.org/10.37745/ejaafr.2013

Ozkan, N., Cakan, S., \& Kayacan, M. (2017). Intellectual Capital and Financial Performance: A Study of the Turkish Banking Sector. Borsa_Istanbul Review, 17(3), 190-198. doi: https://doi.org/10.1016/j.bir.2016.03.001

Pangestika, R., \& Murdianingrum, S. L. (2014). Pengaruh Independensi Dan Efektivitas Komite Audit Terhadap Manajemen Laba (Studi Empiris pada Perusahaan Manufaktur yang Terdaftar di Bursa Efek Indonesia Tahun 2010 - 2012). Jurnal Telaah \& Riset Akuntansi, 7(2).

Putri, S. D., \& Nuzula, N. F. (2019). Pengaruh Intellectual Capital Terhadap Kinerja Keuangan Dan Nilai Perusahaan (Studi pada Perusahaan Sektor Manufaktur yang terdaftar di Bursa Efek Indonesia Periode 2012-2017). Jurnal Administrasi Bisnis (JAB), 66(1), 28-36.

Rachmawati, E. N., Hayati, R., \& Yulandi, F. (2018). The Influence of Intellectual Capital on Financial Performance in Sharia Banking Companies. Paper presented at the Proceedings of the 15th International Symposium on Management (INSYMA 2018). 
Rahmah, A. (2019). Rumus ROA (Return on Asset) dan Contoh Soal Perhitungan ROA. Retrieved from https://rumus.co.id/rumusroa/

Riadi, M. ( 2017, 20 September). Pengertian, Komponen dan Pengukuran Intellectual Capital Kajian Pustaka.

Sayyidah, U., \& Saifi, M. (2017). Pengaruh Intellectual Capital terhadap Nilai Perusahaan Dengan Profitabilitas Sebagai Variabel Moderasi (Studi Pada Perusahaan Sub Sektor Property dan Real Estate di Bursa Efek Indonesia Periode 2013-2015). (Strata 1), Universitas Brawijaya

Administrasi Bisnis. Retrieved from http://administrasibisnis.studentjournal.ub. ac.id/index.php/jab/issue/view/89 (1)

Septia, E. R. (2018). Pengaruh Intellectual Capital Terhadap Nilai Perusahaan (Studi Empiris pada Perusahaan Manufaktur yang Terdaftar di Bursa Efek Indonesia pada Tahun 2014-2016). (Strata 1), Universitas Negeri Padang Retrieved from http://ejournal.unp.ac.id/students/index.ph p/akt/article/view/3782 (Vol. 6 No. 2)

Sharabati, A.-A. A., Jawad, S. N., \& Bontis, N. (2010). Intellectual Capital and Business Performance in The Pharmaceutical Sector of Jordan. Management Decision, 48(1), 105-131.

doi: $10.1108 / 00251741011014481$

Thaib, F. (2013). Value Added Intellectual Capital (VAHU, VACA, STVA) Pengaruhnya Terhadap Kinerja Keuangan Bank Pemerintah Periode 2007 - 2011. Jurnal Riset, Ekonomi, Manajemen dan Akuntnasi (EMBA), 1(3), 151-159. doi: https://doi.org/10.35794/emba.v1i3.1951
Tjandrakirana, H. R., \& Monika, M. (2014). Pengaruh Kinerja Keuangan Terhadap Nilai Perusahaan Pada Perusahaan Manufaktur Yang Terdaftar Di Bursa Efek Indonesia. Jurnal Manajemen dan Bisnis Sriwijaya, 12(1), 1-16.

Ulum, I. (2007). Pengaruh Intellectual Capital Terhadap Kinerja Keuangan Perusahaan Perbankan Di Indonesia. (Master), Universitas Diponegoro., E-Journal UNDIP. Retrieved from http://eprints.undip.ac.id/view/divisions/m ag=5Faccounting/2007.html\#group_A (46)

Vebri, H. (2018). Masalah SDM Jadi Isu Utama Pertemuan IMF-World Bank 2018. Kontan Data.

Wany, E. (2010). Pengaruh Intellectual Capital terhadap Produktivitas, Profitabilitas, Nilai Pasar pada Perusahaan Manufaktur di Bursa Efek Indonesia. AKRUAL, 2(1), 2042. doi: 10.26740/jaj.v2n1.p20-42

Wardana, R. (2019). Menentukan Nilai Perusahaan dan Manfaatnya bagi Bisnis Retrieved from https://lifepal.co.id/media/nilaiperusahaan/

Wergiyanto, Y., \& Wahyuni, N. I. (2016). Pengaruh Intellectual Capital Terhadap Nilai Perusahaan dengan Strategi BersaingSebagai Pemoderasi. Artikel Ilmiah Mahasiswa, 1-5.

Wijayani, D. R. (2017). Pengaruh Intellectual Capital terhadap Kinerja Keuangan Perusahaan Publik di Indonesia (Studi Empiris Pada Perusahaan Manufaktur di BEI 2012-2014). Jurnal Riset Akuntansi dan Bisnis Airlangga, 2(1), 97-116. 